Article

\title{
Welfare Paradoxes and Interpersonal Pacts: Transnational Social Protection of Latin American Migrants in Spain
}

\author{
Laura Oso * and Raquel Martínez-Buján \\ Department of Sociology and Communication Sciences, University of A Coruña, Spain \\ * Corresponding author (laura.oso@udc.es)
}

Submitted: 29 June 2021 | Accepted: 2 December 2021 | Published: 22 March 2022

\begin{abstract}
This article analyses the relationship between migration, care work, and welfare provision, highlighting the role of Latin American migrants in Spain as providers of formal and informal social protection on a transnational scale. It contributes to the debate on transnational social protection and transnational social inequalities from the perspective of welfare paradoxes and interpersonal pacts. Migrant women in Spain have become a resource for the provision of formal social protection through their employment as domestic care workers. Nevertheless, given that access to social rights in Spain depends on job stability and residency status, they have difficulties in accessing formal social protection themselves. This process constitutes a "welfare paradox," based on the commodification and exclusion paradoxes, explained by structural factors such as the characteristics of the welfare regime (familiaristic model, with a tendency to hire domestic workers as caregivers into households), the migration regime (feminised and with a clear leaning towards Latin American women), and the economic landscape resulting from two systemic crises: the great recession of 2008 and the Covid-19 pandemic. Interpersonal pacts, rooted in marriage/couple and intergenerational agreements, and their infringements, are analysed to explain the transnational and informal social protection strategies in the context of the "exclusion paradox" and the breach of the "welfare pact." Our research draws on the exploitation of secondary data and multi-sited, longitudinal fieldwork based on biographical interviews conducted with various members of transnational families in Spain and Ecuador (41 interviews).
\end{abstract}

\section{Keywords}

care work; domestic service; Ecuadorian migration; gender roles; immigration in Spain; social protection; transnational families; welfare

\section{Issue}

This article is part of the issue "Transnational Social Protection: Inclusion for Whom? Theoretical Reflections and Migrant Experiences" edited by Elisabeth Scheibelhofer (University of Vienna), Emma Carmel (University of Bath), and Anna Amelina (University of Cottbus).

(C) 2022 by the author(s); licensee Cogitatio (Lisbon, Portugal). This article is licensed under a Creative Commons Attribution 4.0 International License (CC BY).

\section{Introduction}

Scholarship studying the link between migration, care work, and welfare provision has traditionally focused on the drivers of global care chains (Hochschild, 2000), social care analysis (Daly \& Lewis, 2000), and the circulation of care (Baldassar \& Merla, 2014). In recent years, transnational social protection studies have reviewed reflections on these analyses and contributed new approaches to them. Recently, this analytical framework has been used to argue that the "global care chain" concept was focused principally on highlighting the emotional costs of distance mothering paid by migrant women employed as caregivers and unable to provide their children with the necessary attention and affection. Likewise, the "social care theory" has proved extremely useful in analysing the social models of care and their evolution, even though they are rooted in the notion of social rights associated with nation-states, thereby complicating the identification of transnational protection 
needs (Parella \& Speroni, 2018). Furthermore, it assimilates social protection with the formal sphere, overlooking the informal protection practices that are forged in personal interaction networks. Finally, and although the "circulation of care" concept creates broader areas of care than the previous concepts, it is unable to link the demand for care with "the precarious labour market conditions for migrant care givers" (Lutz, 2018, p. 582) and therefore fails to articulate the exchange of welfare with the structure of global inequality that is the natural habitat of these workers.

In an attempt to bridge these gaps, research on transnational social protection has introduced new conceptualisations that have contributed to an understanding of how the global inequality processes of migrant families (in particular those of female migrant domestic care workers) are articulated with their transnational care strategies. An example of this is the term "assemblage of care" coined by Amelina (2020, 2017). This author argues that the concept allows care to be distanced from the territorial category in which its provision is articulated, enabling the identification of patterns of inequality that emerge precisely during this assemblage. A further contribution to this process is the use of the term "transnational social inequality" (Amelina \& Lutz, 2019), which refers to how the transnational nature of care implies the creation of new hierarchical patterns, which naturally stem from gendered and racialised cultural values regarding care provision, but also from the support for their organisation proffered by public regulations in the host countries, the economic situation, and the regulations governing domestic service. This concept, studied mainly in relation to migrant domestic care workers, links the disadvantaged position of these workers in both the labour market and in the social structure of the host country. This inequality has a localised impact, reflected in migrant marginalisation in relation to the public schemes of social protection, but it also operates in a transnational space as it generates the deployment of cross-border support practices within the family to overcome situations of social risk.

Rooted in the intention to move forward with the theoretical and empirical articulation between the structural processes conditioning global inequalities in access to welfare and the informal practices of mutual support and solidarity deployed among transnational families, the principal objective of this article is to apply the concepts of "welfare paradoxes" and "interpersonal pacts" (focusing on intergenerational and marriage/couple pacts) to the analysis of the formal and informal strategies for the transnational social protection of Ecuadorian migrants in Spain. This article contributes to scholarship in this field firstly through its application of the concept "welfare paradox" to the study of the adverse effects of welfare policies and their connection with cross-border inequalities resulting specifically from formal welfare provision. The "welfare paradox" concept was initially used to analyse the redistribution capacity of universalist welfare policies (Korpi \& Palme, 1998), and more recently to assess the gender-equality impact of work-family reconciliation policies (Kowalewska, 2021). In this reading, we use the term "welfare paradox" to consider the impact of Spanish long-term care policies, based on cash transfers, on the demand for domestic migrant and care workers, as well as the conditioning labour factors that block these workers' access to basic social rights. We argue that this "welfare paradox" is further supported by two paradoxes conceptualised and discussed here, namely the "commodification paradox" and the "exclusion paradox."

Secondly, the article contributes to scientific production debates using the concepts of "intergenerational and couple/marriage pacts" to explore informal transnational social protection strategies. We define the concept of "intergenerational pact" as an implicit agreement, rooted in cultural norms underlying the family sense of solidarity regarding the provision of care between generations (Ayuso, 2012). Beyond the formal marriage contract, which implies a series of rights and obligations for the couple regulated by law, we consider marriage/couple pacts as a series of informal agreements which organise the provision of family welfare. These pacts are obstructed by cultural norms and gender impositions, which traditionally reserve reproductive work for women and confer the traditional role of "breadwinner" on men. The article highlights how intergenerational and marriage pacts account for the articulation of transnational strategies of informal social protection. Such strategies are used by transnational families to offset the effects of the "welfare paradoxes" and their exclusion from the social pacts that are implicit in the nature of welfare states. The originality of our article lies not merely in the fact that it analyses mutual assistance and family support strategies, which have been amply addressed in the literature, but also because it highlights how conflicts and the breakdown of "intergenerational and marriage/couple pacts" account for the explanation of the formal and informal social protection strategies deployed in the transnational space.

Thirdly, the article contextualises transnational social protection from a top-down approach considering informal assistance practices, Spanish welfare policies, and the economic landscape. Previous analyses have been limited in understanding the exchange of goods and services in the regions where migrants settle, whilst structural factors shaping these practices have been overlooked (Hellgren \& Serrano, 2017). "Welfare paradoxes" and "interpersonal pacts" are essentially conceptual tools that connect responsibilities for care (both those held with the transnational family and those that emerge as a result of entering into paid care work) with the economic and political situation of the host country, whilst also revealing how these scenarios activate specific transnational welfare practices (Figure 1).

The article is structured as follows: The next section describes the methodology used, followed by a review of 
how Latin American and Caribbean (LAC) migrant women have become the main providers of "formal social protection" in Spain, addressing in particular social policies aimed at long-term care and describing the "welfare paradox." The fourth section broadens this examination by detailing the informal social protection strategies deployed by Ecuadorian transnational families through the application of the concept of "intergenerational and marriage/couple pacts." The fifth and final section presents the principal conclusions.

\section{Methodology}

The methodology is based on the analysis of secondary data to consider the position of LAC migrant women within the Spanish care model and to explore the scope of formal social protection. The data were obtained from the Spanish Labour Force Survey (INE, 2020), the Spanish Municipal Population Census (INE, 2021), and social service statistics from the Spanish Institute for the Elderly and Social Services (IMSERSO, 2019).

Secondly, the analysis of transnational family social protection strategies is based on multi-sited fieldwork conducted in Madrid and Quito. Biographical interviews with transnational families were held, thereby introducing time, spatial, and intergenerational factors into the analysis of transnational social protection strategies. This methodology also allows the "crossing" of family member narratives, shedding further light on how "interpersonal pacts" are formed and breakdown, as well as on intergenerational and gender relations (for further details see Oso \& Suárez-Grimalt, 2017). Our selection of interviewees was based on gender and generation variables, as well as the type of transnational family, depending on who initiated the migratory process (mothers, fathers, children, or siblings).

The fieldwork also had a longitudinal dimension, as it was conducted over two time periods. Phase one of this research was carried out in 2008, coinciding with the outbreak of the financial crisis, although its impact was yet to make itself felt. It included biographical interviews with persons with family members in Spain, held in a district of southern Quito, together with interviews with key informants. This was followed by interviews with relatives of some of the people contacted in Quito, who had settled in Madrid. Eighteen people were interviewed during the initial phase of our fieldwork (11 women and seven men).

To analyse the impact of the crisis of 2008 on transnational social protection dynamics, a second phase of fieldwork took place in 2015. Contact was re-established with four families who had been interviewed in 2008. Some of the interviews were repeated in Quito and Madrid (eight in total), and new members of the same families were also interviewed for the first time. This longitudinal approach allowed us to monitor the biographical narratives of these families over time. The fieldwork was completed with interviews with other residents of the district, key informants, and a number of returnees in Quito. In this second phase of the fieldwork, 23 interviews (13 women and 10 men) were carried out.

A total of 41 interviews, with 33 people (eight persons were interviewed twice), were carried out throughout the two-phased fieldwork: 19 women and 14 men (15 of whom were members of the chosen four monitored families). A further phase of the fieldwork was initiated in 2021 to analyse the impact of the Covid-19 crisis. To date, one of the four monitored families has been interviewed (Table 1).

We have illustrated the analysis of empirical data with the interviews of the monitored family cases, discussing those testimonies that best illustrate the articulation of interpersonal pacts and their infringements for transnational social protection provision. The analysis is based on a grounded theory approach (Charmaz, 2005).

\section{Migration, Domestic Care Work, and the Welfare Paradox From a Transnational Approach}

According to Eurostat, $49.1 \%$ of the Latin American migrant population resident in the European Union has settled in Spain (Bayona-i-Carrasco \& Avila-Tàpies, 2019), where this group accounts for $3.1 \%$ of the total population and $40.2 \%$ of the foreign-born population (see INE, 2021; the Spanish Municipal Population Census is an administrative register that includes demographic data and, in the case of the migrant population, also includes those people with an irregular status; in Spain, registration is compulsory and it is a reliable source of foreign population data, as inclusion on this register is a requirement for access to healthcare and education). Spain's economic growth, a growing demand in Spain for domestic and care workers, and migration policies drawn up in the context of post-colonial relations with visa regulations and less restrictive citizenship requirements for LAC population (who are entitled to Spanish citizenship after two years of legal residence in the country, compared to ten years for people from other regions), have been the key triggers for the settlement of migrants, in particular women (Bertoli \& Fernández-Huertas, 2013). In 2020 , the feminisation rate stood at $56.9 \%$.

Domestic service is the biggest sector of employment for female migrant workers, who account for $17.8 \%$ of the workforce. This figure is higher in the case of women from the LAC region, which provides $64.3 \%$ of the workers in domestic service. In contrast to $24.9 \%$ of domestic and care workers from Europe, 3.8\% from Asia, and $7.1 \%$ from Africa. In 2020, the number of domestic workers stood at 454,000 and around $63.7 \%$ of these employees are female migrants (see INE, 2020; the Spanish Labour Force Survey includes workers both in a regular and an irregular situation). The concentration capacity of the migrant population in this sector has been addressed in numerous studies, which indicates that growth in this sector is linked mainly to household care requirements that are inherent to population 
Table 1. Description of the transnational families interviewed.

\begin{tabular}{|c|c|c|c|c|c|}
\hline $\begin{array}{l}\text { Transnational } \\
\text { family }\end{array}$ & Description & $\begin{array}{l}\text { Family members } \\
\text { in Ecuador }\end{array}$ & $\begin{array}{l}\text { Family members } \\
\text { in Spain }\end{array}$ & \multicolumn{2}{|c|}{$\begin{array}{l}\text { Family member interviewed; } \\
\text { Interview place and date }\end{array}$} \\
\hline María & $\begin{array}{l}\text { Family comprising } \\
\text { the mother, } \\
\text { Magdalena, her } \\
\text { three daughters } \\
\text { (María, single, } \\
\text { Lucía and Ana, } \\
\text { separated), and } \\
\text { their three } \\
\text { descendants }\end{array}$ & $\begin{array}{c}\text { Mother, youngest } \\
\text { daughter (Ana), } \\
\text { and Ana's } \\
\text { daughter }\end{array}$ & $\begin{array}{c}\text { María, Lucía, and } \\
\text { Lucia's two } \\
\text { daughters }\end{array}$ & $\begin{array}{c}\text { Magdalena and } \\
\text { younger sister } \\
\text { Quito, 2008-2015 }\end{array}$ & $\begin{array}{c}\text { María and Lucía } \\
\text { Madrid, } \\
\text { 2008-2015 }\end{array}$ \\
\hline Graciela & $\begin{array}{l}\text { Family comprising } \\
\text { a divorced couple } \\
\text { and two sisters } \\
\text { (one is married } \\
\text { and has two } \\
\text { descendants) }\end{array}$ & $\begin{array}{l}\text { Father, who is } \\
\text { currently living } \\
\text { with another } \\
\text { woman (who has } \\
\text { two children from } \\
\text { a previous union) } \\
\text { and has had a } \\
\text { daughter with her }\end{array}$ & $\begin{array}{l}\text { Graciela, mother, } \\
\text { and sister } \\
\text { (together with the } \\
\text { sister's husband } \\
\text { and descendants) }\end{array}$ & $\begin{array}{l}\text { Graciela's father } \\
\text { Quito, } 2008\end{array}$ & $\begin{array}{c}\text { Graciela } \\
\text { Madrid, } \\
\text { 2008-2015, } 2021\end{array}$ \\
\hline Manuel & $\begin{array}{l}\text { Family comprising } \\
\text { a divorced couple, } \\
\text { four children, and } \\
\text { a grandchild }\end{array}$ & $\begin{array}{l}\text { Mother, two } \\
\text { middle sons, and } \\
\text { the youngest } \\
\text { daughter }\end{array}$ & $\begin{array}{c}\text { Manuel (father), } \\
\text { eldest daughter, } \\
\text { and } \\
\text { granddaughter }\end{array}$ & $\begin{array}{l}\text { Mother, two } \\
\text { middle sons, and } \\
\text { the youngest } \\
\text { daughter } \\
\text { Quito, 2008-2015 }\end{array}$ & $\begin{array}{c}\text { Manuel } \\
\text { Madrid, } \\
\text { 2008-2015 }\end{array}$ \\
\hline Elvira & $\begin{array}{c}\text { Family comprising } \\
\text { a couple, three } \\
\text { children (Elvira } \\
\text { and another two), } \\
\text { and two } \\
\text { grandchildren }\end{array}$ & $\begin{array}{l}\text { Father (in a union } \\
\text { with another } \\
\text { woman following } \\
\text { the mother's } \\
\text { death), elder } \\
\text { brother (with his } \\
\text { wife and son), } \\
\text { youngest sister }\end{array}$ & $\begin{array}{l}\text { Elvira, who lived } \\
\text { in Madrid, but } \\
\text { who was residing } \\
\text { in Buenos Aires } \\
\text { in } 2017\end{array}$ & $\begin{array}{l}\text { Mother, eldest } \\
\text { brother, and } \\
\text { Elvira's father } \\
\text { Quito, 2008-2015 }\end{array}$ & $\begin{array}{c}\text { Elvira interviewed } \\
\text { in Madrid in } 2008 \\
\text { and in Buenos } \\
\text { Aires in } 2017\end{array}$ \\
\hline
\end{tabular}

Total number

of monitored

family members

Other people

interviewed
15 ageing, changes in family structures, and the increasing participation of women in the labour market (Moré, 2018). Scholars also agree that the spread of this activity is associated with the increasingly international nature of the gendered work division, which would explain why it includes a large number of female migrant workers (Barañano \& Marchetti, 2016). The concentration of LAC workers is attributable to the fact that this group fits in with the image of an ideal postcolonial Spanish speaking worker with catholic values that are perfectly aligned with domestic tasks in general and care work in particular (Castellani \& Martín-Díaz, 2019).

The spread of public policies addressing long-term care based on cash transfers rather than social services is another key factor in the consolidation of the commodification of these tasks on care work to migrants (Picchi, 2016). These cash transfers act as a subsidy given directly to the families, enabling them to acquire, in the private market, the social service deemed appropriate by the public system ("economic benefit linked to a social care service": $10.7 \%$ of long-term public care system users in 2019) or to have close relatives providing care work ("economic benefit for care in the family environment": $30.3 \%$ of users in 2019). Several studies (e.g., Díaz \& Martínez-Buján, 2018) have shown that the money granted for the care of family members through "economic benefit for care in the family environment" is being used to pay private carers hired through domestic 
service, partly because there is no way of monitoring the way the money received is used. The co-pay mechanism linked to service-related financial subsidies has also contributed to this process. It was established in the light of the austerity policies introduced during the global financial crisis of 2008 and consists of users making a financial contribution that would complete the cost of the social service acquired through this programme. The issue is that co-payment is income indexed and the principal limitation is that this amount is very high, even for those on average or low incomes.

As an example, the average cost of a place in a care home in Spain is 1,800 euros (IMSERSO, 2019). For a person with a high degree of dependence, the maximum subsidy is 715 euros, provided that their monthly income does not exceed 565 euros. This user would have to pay the difference; in other words: 1,085 euros, more than their disposable income. The same is true of home-based care. The cost per hour for this service in an average-sized municipality is 12.70 euros. A severely dependent person would receive a maximum of 70 hours per month (Martínez-Virto \& Hermoso, 2021) at a cost of some 889 euros. Considering that the average pension in Spain is 1,140 euros, co-payment for this service would be $30 \%$, whereby the user would pay 267 euros for just two hours of care per day. As a result, many users are unable to pay the stipulated co-pay and resort to domestic service as a more economical and flexible way of filling their care requirements.

This situation indicates a contradiction between the philosophy underlying the design of public resources and the adverse effects that arise during their application. We have coined this process as a "welfare paradox" (in line with the terminology of earlier authors mentioned in the introduction) that impacts not only on the actual users but also on the care strategies of the family environment and other provision areas. We posit that two clearly differentiated "welfare paradoxes" can be identified. On the one hand, the social resources referred to above are immersed in a "commodification paradox," in that they have proved incapable of decommodifying care and are reduced to subsidies that complement the hiring of domestic service, or discourage the use of public social services due to the cost involved for beneficiary families. In other words, these measures fail to reduce individuals' dependence on the market. Back in the 1990s, feminist scholars were already calling for the need to highlight the "commodified" dimension to guarantee equal access to public resources (Orloff, 1993). If we include co-payment in the equation, stratification regarding who can or cannot access certain social services becomes even more pronounced. On the other hand, this contradiction interacts simultaneously with the strategies adopted by Spanish families to resolve their needs and is also connected with the conception of a dualized welfare state that differentiates workers based on their entitlement to labour and social rights. In this way, we find, at one extreme, well-paid workers who have access to welfare protection and, at the other extreme, we have precarious, low-paid, and unprotected workers. This segmentation, according to Castellani (2020, p. 3) "has configured a dualized welfare, which creates a class of 'worker citizens,' the 'insiders,' who contribute to the welfare state and are entitled to its benefit and a subclass of 'working poor,' the 'outsiders,' who have limited access to welfare benefits." It is complemented with a further stratification layer among domestic migrant care workers comprising ethnicity, legal status, and migration policies. All these processes create an "exclusion paradox" that blocks the migrant population's access to the social rights enjoyed by other citizens, as they experience greater difficulties in maintaining contributions throughout their labour trajectory (Figure 1).

This impact is particularly harsh in the case of domestic migrant care workers, who are also bound by a much more restrictive framework for the protection of their labour rights than other workers. This legal framework permits cease and desist dismissals (whereby the employing family can fire a worker at any time they deem fit), non-entitlement to unemployment benefits (even though they are legally employed), exclusion from the Occupational Risks Prevention Law, and the absence of work inspections in the private households that employ them (Molero-Marañón, 2020). This situation places them in a position of extreme vulnerability, particularly during periods of systemic crisis. During the recession of 2008, even though many domestic care workers remained at work, the continuous wage cuts and worsening working conditions were clearly in evidence on multiple occasions (Hellgren \& Serrano, 2017). During the Covid-19 crisis, when they suddenly became essential workers due to the particular vulnerability to the virus of the elderly population, their working conditions were so precarious that they became the most vulnerable workers of the pandemic (ILO, 2020). The introduction of the Spanish government's "Extra Subsidy for Domestic Service Workers," for workers who had lost their jobs or had seen their working hours reduced as a result of the health emergency, did little to ease the situation (the subsidy was up to $70 \%$ of their contributionbased earnings, up to a maximum of 950 euros, the minimum salary for 2020). The condition of being registered with in the social security system detracted from its universalising effect as it is estimated that $30 \%$ of domestic and care workers are in the underground economy (Díaz \& Martínez-Buján, 2018). This situation together with the delay in its introduction (applications were not accepted until May 2020) and late payments (which in some cases extended to up to three months following application) have further worsened these workers' living conditions, forcing them to resort to informal means of support or seek aid from voluntary organisations to cover their essential needs (Díaz \& Elizalde-San Miguel, in press). Consequently, distanced from the "social pact" that formed the foundations for the welfare state and the inability of social protection mechanisms to act quickly 
and effectively in the light of an emergency, adopting transnational strategies for achieving social protection has become an essential resistance strategy.

The following section, based on our fieldwork, presents the arguments that show how these informal social protection strategies, aimed at offsetting the paradox of exclusion and the breach of the "welfare pact," are based on interpersonal agreements rooted in marriage/couple and intergenerational pacts and their infringements. The tension between relationships of solidarity and conflicts underlie the adoption of informal social protection strategies and their articulation with formal ones on a transnational scale, within the framework of the "welfare paradox."

\section{Intergenerational and Marriage/Couple Pacts in Social Protection Strategies of Transnational Families}

Transnational social protection strategies are based on intergenerational family pacts that may involve mothers/fathers, grandmothers/grandfathers, sons/ daughters, brothers/sisters, and nephews/nieces, underpinned by the sense of family solidarity and the obligation to provide welfare (Ayuso, 2012), as reflected in María's testimony:

For us, the mother and father are sacred. It's as if they were our children; like we have a lifelong obligation to repay them for everything they have given us. As they have protected us and continue to do so up until now, now that they are older and have worked so hard, it's time for the children to play their part. (María, Madrid, 2008)

Transnational protection strategies are also articulated through marriage/couple pacts. In addition to their legal basis, which implies certain welfare rights and obligations before the parts involved, marriage/couple pacts are also grounded in cultural values and gender imperatives. As Pateman explained (1988), the sexual contract is also the principle of the marriage contract. Indeed, both the intergenerational and marriage/couple pacts are conditioned by gender roles. As Cortés and Oso (2017) point out, women are expected to play a greater role in the provision of welfare through care, whilst men's contribution to the family welfare is essentially through their status as the breadwinner. However, the roles in the intergenerational pact are disrupted in the case of those families in which the woman acts as the pioneer in the migratory chain, leaving the children behind. The gender rules are broken when these women leave their role as "in-person carers," delegating it to a third person in the country of origin, and assume the responsibility for family welfare through remittances (Cortés \& Oso, 2017). This situation is occasionally sanctioned by the children left behind in the country of origin, who may perceive that the emotional dimension of the intergenerational pact has been broken. It occurs less in the case of men who migrate alone, leaving their wives and descendants behind, as they assume the traditional role of breadwinner.

Graciela's mother was one of the women that pioneered the migration process in their family following Ecuador's economic crisis at the end of the 20th century, travelling to Spain to work as a domestic and care worker. Her migration was part of an intergenerational transnational social protection strategy to provide their daughters, who initially remained in Quito with their father, with a university education, which is very expensive in Ecuador. The interview with Graciela reveals our informant's perception of an emotional collapse of the intergenerational pact after her mother migrated: "I was 13 when my mother emigrated, and my feelings were of abandonment" (Graciela, Madrid, 2015).

In another example, Manuel's children, who were left with their mother in Quito, see their father's emigration in a more positive light, even though the couple separated and Manuel settled down with a new family in Madrid (couple and daughter). His wife in Quito accepted this new relationship because, even though he had broken the emotional dimension of their marriage pact, Manuel upheld his responsibilities before the intergenerational pact with their children through remittances, therefore complying with his assigned role as the breadwinner. Thanks to their father's financial support, all three children were able to attend private schools in Ecuador and undertake vocational training or university courses as part of an education-based transnational social protection strategy. Nevertheless, the mother did not want to grant Manuel a divorce because she feared that, after the formal break-up of the marriage pact, he would marry the other woman. A new marriage pact could have an impact on her children's inheritance:

I'm not giving him the divorce, because he left to look after the family. He is with another woman, but she doesn't stop him from sending me money. If I want him to continue to support me financially, I can't say anything. (Manuel's wife, Quito, 2015).

It is therefore clear that emotions also play a part in intergenerational pacts. A connection can be drawn between the emotional ties and the strength of the pact: The severance of these ties, the loss of affection, or family quarrels can articulate the agreements on which the transnational social protection is based (Oso, 2016).

Magdalena's oldest daughter Lucía was the first to leave the country, followed by Lucía's husband, their two daughters, and her middle sister, María, the only one who remained single and had no children. Lucía separated from her husband in Spain, shortly after he arrived in Madrid. The two sisters and Lucía's two daughters lived together in an apartment and worked in the domestic, care, and cleaning sectors. After the breakdown of her marriage pact and her ex-husband's lack of responsibility towards their daughters, this situation helped Lucía 
as a strategy of informal social protection. The two sisters shared the care of the daughters, who were still young children at the time. María took care of her nieces as part of an intergenerational family welfare pact. Likewise, at the beginning of the migration cycle, the two migrant sisters provided financial support for the family back in Quito, a measure of transnational informal social protection that helped face their mother's ineligibility for a retirement pension and public healthcare, the medical expenses incurred by the premature birth of their niece, and the fact that both their sister Ana and her husband were unemployed in Quito. The remittances sent by the migrant sisters were the principal source of income for the household in Ecuador. In addition to the money they sent from Spain for daily expenses, María sent money to build an apartment for herself above their mother's house. This apartment was occupied by her youngest sister's family (Ana, her husband, and the niece) as a form of informal social protection in terms of the provision of housing:

My family depend on us $100 \%$. My mother doesn't work [and] neither does my sister. The youngest, my niece, was born prematurely and we paid for all the hospital fees from here. Now, her husband is unemployed after he was dismissed, and we have to feed the four of them and the child, who is still a baby....We work for others to live....My mother no longer receives public healthcare, she now has a private doctor to treat her ailments. (María, Madrid, 2008)

However, the family in Ecuador was aware of the need to have a good relationship with María to ensure that she would not question the intergenerational pact that guaranteed remittances:

Now that we are so far apart, my sister back in Ecuador is much more affectionate towards me, just like my mum. She is closer to us and respects us more. She used to say whatever she felt like, but now she bites her tongue. Firstly, because she says that we are the elder sisters, and secondly because they depend on us-because, otherwise, we would stop sending money. Because when I get mad, I stop everything. (María, Madrid, 2015)

The onset of the 2008 economic crisis entailed the restructuring of the social protection strategies of the transnational family. Both Lucía and María experienced a sharp reduction in their working hours in the domestic service and cleaning sectors, which led to a substantial decrease in their income. They were blocked by the "exclusion paradox." The two sisters had a row, which prompted María to move into a small apartment all by herself in another area of Madrid, where she was living in 2015. Lucía's financial situation was quite precarious after the breakdown of the intergenerational pact with her sister. She had to turn to church as a form of social protection to receive food. She also occasionally received remittances sent by her mother in Ecuador, as the economic situation of the family back in Quito had improved considerably (Magdalena was awarded a pension and her daughter Ana found a job). María is still helping her nieces in Spain at this point, giving them money for food and clothing whenever she sees that the financial situation is dire. The youngest niece had moved in with her in 2015 as a means of social protection given the difficult situation that Lucía was going through. This indicates that intergenerational social welfare pacts are reestablished over time and that transnational social protection strategies are forged by the strength or breakdown of emotional ties, but also in light of the impact of the "exclusion paradox."

The intergenerational support pact of descendants towards their parents, or uncles and aunts towards their nephews and nieces, should supposedly be stronger in the case of single-family members. This is due to the conflict between intergenerational pacts and marriage/ couple pacts, especially where descendants are involved. Some of our female informants explained how they had to conceal the remittances they sent to their parents and siblings from their partners. Indeed, parents' intergenerational pacts with their children take precedence over all others:

I send money to my mother every month without fail. My sister was off sick for around six months and she said [to me]: "I can't send money to mum, because those ten euros are for my daughters' milk." Or don't have children, if you have a partner, as they won't let you send money back to the family. Because the money is for the family, in other words, the husband, wife, and their children. As I'm single, they expect more from me. She says: "It's because you don't have any expenses; you're single, you don't have children." It's like, you have to send money because you just have to. (María, Madrid, 2008)

This clash between intergenerational and marriage/ couple pacts is also reflected in the case of Elvira, who, at the start of her migratory experience, sent back half her salary, working in the domestic/care and catering sectors, to her mother. The money was invested in expanding the family business in Quito as part of an intergenerational social protection strategy. This safeguarded her brother's job and led to an overall improvement in the family's circumstances, and also enabled her younger sister to study at university. However, our informant's marriage to a fellow Ecuadorian she met in Madrid put a stop to these remittances over several years, and they were only renewed following the couple's separation:

In the beginning, I would send money back to my mother, which enabled her to purchase computers to set up a business, and also to help my brother and my sister....There was a period when I didn't send 
anything-that was when I got married-because you have other responsibilities. We had a mortgage and he [her husband] and I had to find the money for our expenses....Later, when we separated, I was able to start sending money again. (Elvira, Madrid, 2008)

Following the onset of the economic crisis in 2008, Elvira, faced with the "exclusion paradox," decided to return to Ecuador in 2014. However, she was unable to find her place in Quito. After the death of her mother, her father embarked on a sentimental relationship with another woman (a new couple pact) which interfered with the intergenerational pact. Elvira does not accept this union and begins to claim her space, questioning the father's authority, leading to family rows. She decides to migrate again, this time to Buenos Aires. All this leads to a breach in the intergenerational pact with her father:

For me, it was not positive that she has built a bigger house, a better business.... She no longer has the same respect that she had back then, the respect seems to have gone. (Elvira's father, Quito, 2015)

In turn, intergenerational pacts are a means of ensuring social protection when a marriage/partnership breaks down. This is the case of Lucía (Magdalena's daughter), who, after separating from her husband, turned to her sister María for help.

To further illustrate this idea, we turn to the family history of Graciela, who initially stayed in Ecuador following her mother's migration. The family regrouped in Spain, but Graciela's father felt unsettled and ended up going back to Ecuador. He and his wife separated and finally divorced-which resulted in the breakdown of their marriage pact. In 2021, the father was living with a new partner and the couple now has a three-yearold daughter. His partner has two older children from a previous relationship who are studying at the university. Following a history of domestic violence at the hands of the father, Graciela has made it clear to him that he must cherish the relationship with his new daughter and her step-siblings because they will have to care for him when he is older. The abuse that the women of the family (Graciela, her older sister, and their mother) suffered and the father's decision to settle permanently in Quito brought about a breach in the intergenerational contract between the man and the three women. Graciela has urged her father to safeguard the new pact with the younger generation of his family and his partner in Ecuador as a means of social protection that will ensure he is cared for in the future:

I tell my dad: Behave towards them as you didn't behave towards us-be a father. I tell him: Take advantage of this opportunity, maybe they will look after you when you are old, because we won't be able to. (Graciela, Madrid, 2021)
The breakdown of the marriage pact with the father lies at the heart of the precariousness the family experienced in the wake of the 2008 recession. The mother lost her job and had no form of social protection because, as a domestic service worker, she was not entitled to any form of unemployment benefits. She was blocked by the "exclusion paradox." Her husband, who settled in Quito, was not sending money to Spain, instead employing his financial resources on his own upkeep in Ecuador. In this case, he fails to assume his role as breadwinner.

The intergenerational pact forged between the three women became the sole form of social protection open to the family to face the welfare paradox, providing various degrees of support. The elder sister, who got married in Spain, had two children and moved to another flat with her husband. She acted as a permanent link in this chain of intergenerational social protection support. Thanks to her husband's financial support (a new marriage pact) with household expenses, the elder sister was able to finance the costs of the flat Graciela and her mother lived in and also provided meals for her mother during times of greatest hardship. Thanks to her sister's help, Graciela was able to study at the university and, as a result, found a skilled job in Madrid that enabled her to send remittances to her mother. In turn, the mother cares for the grandchildren and helps with domestic chores, thereby supporting her elder daughter, whose working hours in the catering industry, coupled with the lack of state support for families in Spain, make securing a life-work balance a challenging task.

Unlike the 2008 recession, which impacted most severely on the building industry, the Covid-19 crisis had a devastating impact on the catering sector, where Graciela's elder sister and brother-in-law worked. Thanks to state social protection and specific aid for workers who lost their jobs during the health emergency (the furlough scheme known as ERTE), the couple were able to get through the recession, albeit on a far lower income. However, all members of the family who had settled in Spain, except for Graciela, caught coronavirus (her sister, brother-in-law, mother, niece, and nephew). This situation placed Graciela under great emotional stress, as she was in Madrid and extremely concerned about her family's health. Her mother also suffered, as she was afraid of dying due to her age and health problems. In turn, the elder sister suffered panic attacks because of concerns over the family's health problems and the after-effects of the disease she was personally experiencing. The family being separated (Graciela is alone in Madrid) and the lack of a solid social network made it difficult for them to manage the health emergency:

We don't have a family network here [Spain]. My sister is ill and I'm not there to look after the children and take the medication to my mum. We don't have a strong, consolidated network. The fact that we don't have a family network, which I really miss, makes everything very difficult. (Graciela, Madrid, 2021) 
In turn, Graciela was forced to go through the health emergency alone, working from home without seeing anyone, which also caused health issues. Faced with an emotional crisis, the intergenerational pact between women is activated, this time based on silence:

A close bond of solidarity has been forged between us: We look after one another by not talking about what we're going through. How are you? Great, fantastic, even though we all have health problems.... How are you? I'm fine. Sure? Yes, mum, I'm good. (Graciela, Madrid, 2021)

This family's history highlights how the pacts and their eventual breakdown shape informal social protection strategies, which are combined with others of a more formal nature. The breakdown of the marriage pact between husband and wife, together with the mother's low income and her non-entitlement to unemployment benefits as a domestic service worker ("exclusion paradox"), worsened the precarious position of the family in Spain after the 2008 crisis. In turn, an intergenerational social protection chain formed by the three women was forged to secure the younger daughter's education and offset the mother's unemployment and the elder daughter's difficulties in balancing work and family. In addition to this chain, a pact of silence was established after the Covid-19 crisis which guarantees emotional stability. In Ecuador, the crisis caused by Covid-19 has been managed thanks to state social protection in the form of the father's pension, as well as the possibility of informal employment in the father's carpentry workshop, helped by his partner when she loses her job as a domestic worker in Quito. In addition, the family members living in Ecuador occasionally call on Graciela's sense of solidarity when they are in debt or need to make a particular purchase. Finally, due to the father's abusive behaviour, the distance that resulted from his decision to settle in Ecuador, and his failure to assume the role of breadwin- ner, any future care of the progenitor will depend on the strength of a new intergenerational pact with his youngest daughter and his new partner's other children in Quito (Figure 1).

\section{Conclusion}

The first contribution of this article to the debate on transnational social protection is the application of the "welfare paradox" concept to show how formal social protection of long-term care in Spain has resulted in the emergence of a labour market for domestic service which centres the activity of migrant women, in particular of LAC origin ("commodification paradox"). Simultaneously, this process interacts with the difficulties these workers experience in accessing public social benefits, due to their non-contribution to the social security system and the legal framework that regulates domestic service ("exclusion paradox"). Expelling these workers from the "social welfare contract" in turn leads to the configuration of informal transnational social protection strategies, particularly in contexts of crisis and social risk. A review of the public system for long-term care in Spain is also necessary to revert this situation. The elimination of the co-pay mechanism and the option of hiring professional carers through monetary transfers are two criteria that could be monitored in the mid-term. The ratification of ILO conventions 189 and 190 and the equation of the working conditions of domestic caregivers to other employees are key criteria to minimise processes of social exclusion.

The second contribution of this article is the analysis of the fieldwork conducted with Ecuadorian transnational families, which has revealed how these informal social protection strategies are supported by interpersonal pacts (intergenerational and marriage/couples) that are sustained by cultural norms and gender imperatives. These pacts are the result of relationships of solidarity, although they are not free from conflict. As a

TRANSNATIONAL SOCIAL PROTECTION

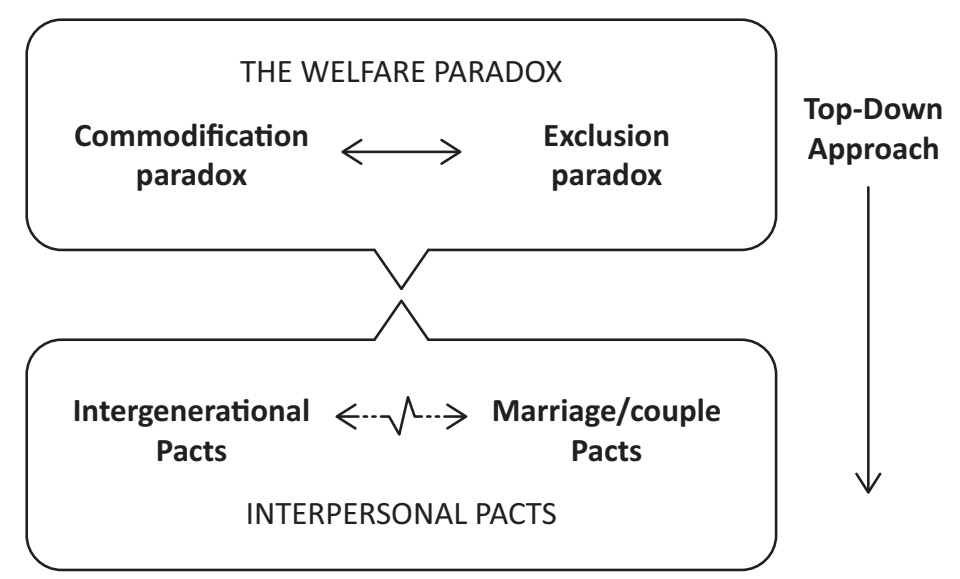

Figure 1. The "welfare paradox" and the "interpersonal pacts" in transnational social protection. 
result, any breakdown in these pacts may also determine the nature of the transnational social protection strategies deployed. This tends to result in the activation of intergenerational pacts when marriage/couple pacts are weakened and vice versa. It is in the interplay of this tension between interpersonal pacts of solidarity, their breakdown and the exclusion in terms of the "social welfare pact," that formal and informal social protection strategies come into play, applied within the transnational space.

Finally, the article highlights how the exchange of welfare between transnational families is linked to structural factors, a top-down analysis that has been hitherto overlooked in studies on transnational social protection.

\section{Acknowledgments}

This work was funded by Joint Programming InitiativeMore Years, Better Lives (Spanish Ministry of Science and Innovation) under the Care, Inequality and Wellbeing in Transnational Families in Europe: A Comparative Intergenerational Study in Spain, France, Sweden and UK research project (grant number PCI2021121924), and by the Spanish Ministry of Science and Innovation itself under the research projects The Model of Long-Term Care in Transition: Political, Family and Community Strategies to Face the Consequences of the Covid-19 Pandemic (grant number PID2020-114887RBC33), Gender, Crossed Mobilities and Transnational Dynamics (grant number FEM2015-67164-R), and The Impact of Immigration on Development: Gender and Transnationalism (grant number SEJ2007-63179). The authors would like to thank their reviewers for their detailed suggestions on earlier drafts of this article.

\section{Conflict of Interests}

The authors declare no conflict of interests.

\section{References}

Amelina, A. (2017). Transnationalizing inequalities in Europe: Sociocultural boundaries, assemblages, regimes of intersection. Routledge.

Amelina, A. (2020). Theorizing large-scale societal relations through the conceptual lens of cross-border assemblages. Current Sociology, 69(3), 352-371. https://doi.org/10.1177/0011392120931145

Amelina, A., \& Lutz, H. (2019). Gender and migration: Transnational intersectional prospects. Routledge.

Ayuso, L. (2012). El deber de apoyar a la familia: Una revisión del pacto intergeneracional de ayudas familiares en España [The duty to support the family: A review of the intergenerational pact of family aid in Spain]. Panorama Social, 15, 143-158.

Baldassar, L., \& Merla, L. (2014). Transnational families, migration and the circulation of care: Understanding mobility and absence in family life. Rouledge.
Barañano, M., \& Marchetti, S. (2016). Perspectives on gender, migration and transnational work: Joint work of social reproduction and care in Southern Europe. Investigaciones Feministas, 7(1), 9-33. https://doi. org/10.5209/rev_INFE.2016.v7.n1.53094

Bayona-i-Carrasco, J., \& Avila-Tàpies, R. (2019). Latin Americans and Caribbeans in Europe: A cross-country analysis. International Migration, 58(1), 198-218. https://doi.org/10.1111/imig.12565

Bertoli, S., \& Fernández-Huertas, J. (2013). Multilateral resistance to migration. Journal of Development Economics, 102, 79-100. https://doi.org/10.1016/ j.jdeveco.2012.12.001

Castellani, S. (2020). On the fringes of social protection: New Southern European labour migration to Germany. International Migration. Advance online publication. https://doi.org/10.1111/imig.12760

Castellani, S., \& Martín-Díaz, E. (2019). Re-writing the domestic role: Transnational migrants' households between informal and formal social protection in Ecuador and Spain. Comparative Migration Studies, 7(7). https://doi.org/10.1186/s40878-018-0108-0

Charmaz, K. (2005). Charmaz grounded theory in the 21st century. Applications for advancing social justice studies. In N. K. Denzin \& Y. S. Lincoln (Eds.), The SAGE handbook of qualitative research ( $\mathrm{pp}$. 507-536). SAGE.

Cortés, A., \& Oso, L. (2017). Avecillas y pájaros en vuelo transnacional: Retorno, género y estrategias de movilidad e inmovilidad entre Ecuador y España [Birds of a feather in transnational flight: Return, gender and mobility-immobility strategies between Ecuador and Spain]. Revista Española de Sociología, 26(3), 359-372. https://doi.org/10.22325/ fes/res.2017.28

Daly, M., \& Lewis, J. (2000). The concept of social care and the analysis of contemporary welfare states. British Journal of Sociology, 51(2), 281-298. https:// doi.org/10.1111/j.1468-4446.2000.00281.x

Díaz, M., \& Elizalde-San Miguel, B. (in press). La inevitabilidad de los empleos de cuidado: La crisis de la COVID como reflejo de las limitaciones sociales y jurídicas en el sector del empleo del hogar [The inevitability of careviging jobs: COVID crisis as a reflection of social and legislative limitations in the domestic sector]. Migraciones.

Díaz, M., \& Martínez-Buján, R. (2018). Mujeres migrantes y trabajos de cuidados: Transformaciones del sector doméstico en España [Migrant women and care work: Transformations of the domestic sector in Spain]. Panorama Social, 27, 105-118.

Hellgren, Z., \& Serrano, I. (2017). Transnationalism and financial crisis: The hampered migration projects of female domestic workers in Spain. Social Sciences, 6(1). https://doi.org/10.3390/socsci6010008

Hochschild, A. R. (2000). Global care chains and emotional surplus value. In W. Hutton \& A. Giddens (Eds.), On the edge: Living with global capitalism (pp. 
130-46). Jonathan Cape.

ILO. (2020, June 16). La COVID-19 pone en jaque el sustento de más de 55 millones de personas dedicadas al trabajo doméstico [COVID-19 jeopardizes the livelihoods of more than 55 million people engaged in domestic work]. OIT Noticias. https:// www.ilo.org/global/about-the-ilo/newsroom/news/ WCMS_748117/lang--es/index.htm

Korpi, W., \& Palme, J. (1998). The paradox of redistribution and strategies of equality: Welfare state institutions, inequality, and poverty in the western countries. American Sociological Review, 63(5), 661-687. https://doi.org/10.2307/2657333

Kowalewska, H. (2021). Bringing women of board? Family policies, quotas and gender diversity in top jobs. Work, Employment and Society, 35(4), 735-752. https://doi.org/10.1177/0950017020971221

Lutz, H. (2018). Care migration: The connectivity between care chains, care circulation and transnational social inequality. Current Sociology, 66(4), 577-589. https://doi.org/10.1177\%2F00113921187 65213

Martínez-Virto, L., \& Hermoso, A. (2021). Hacia un modelo público de cuidados en la comunidad [Towards a public model of community care]. Revista Española de Sociología, 30(2). https://doi.org/10.22325/fes/ res.2021.26

Molero-Marañón, M. L. (2020). Las trabajadoras del cuidado: Por un futuro de trabajo decente [Care workers: For a future of decent work]. Revista de Derecho Social, 89, 33-64.

Moré, P. (2018). The limits of care. Organisation of the household assistance for the elderly in Madrid and Paris. Revista Internacional de Sociología, 76(1). https://doi.org/10.3989/ris.2018.76.1.16.25

Orloff, A. S. (1993). Gender and the social rights of citizenship. American Sociological Review, 58(3), 303-328. https://doi.org/10.2307/2095903

Oso, L. (2016). Migración ecuatoriana y estrategias familiares de movilidad social: La relación dialéctica entre el capital financiero y emocional [Ecuadorian migration and family strategies for social mobility: The dialectical relationship between financial and emotional capital]. Investigaciones Feministas, 7(1), 221-240. https://doi.org/10.5209/ rev_INFE.2016.v7.n1.51739

Oso, L., \& Suárez-Grimalt, L. (2017). Migración y estrategias intergeneracionales de movilidad social: Retos teóricos y metodológicos [Migration and intergenerational strategies of social mobility: Theoretical and methodological challenges]. Migraciones, 42, 19-41. https://doi.org/10.14422/mig.i42.y2017.002

Parella, S., \& Speroni, T. (2018). Las perspectivas transnacionales para el análisis de la protección social en contextos migratorios [Transnational perspectives for analyzing social protection in the context of migration]. Autoctonía, 2(1), 37-56. https://doi.org/ 10.23854/autoc.v2i1.59

Pateman, C. (1988). The sexual contract. Stanford University Press.

Picchi, S. (2016). The elderly care and domestic services sector during the recent economic crisis. The case of Italy, Spain and France. Revista de Investigaciones Feministas, 7(1), 169-190. https://doi.org/10.5209/ rev_INFE.2016.v7.n1.52067

Spanish Institute for the Elderly and Social Services. (2019). Informe anual IMSERSO 2019 [IMSERSO annual report 2019]. https://www.imserso.es/ imserso_01/el_imserso/informes_anuales/ informe2019/index.htm

INE. (2020). Encuesta de población activa 2020: Resultados [Labor force survey 2020: Final results]. https://www.ine.es/dyngs/INEbase/es/operacion. htm?c=Estadistica_C\&cid $=1254736176918 \&$ menu= ultiDatos\&idp=1254735976595

INE. (2021). Padrón municipal de habitantes 2021: Resultados [Spanish municipal population census 2021: Results]. https://www.ine.es/dyngs/INEbase/ es/operacion.htm?c=Estadistica_C\&cid=12547361 77012\&menu=ultiDatos\&idp $=1254734710990$

\section{About the Authors}

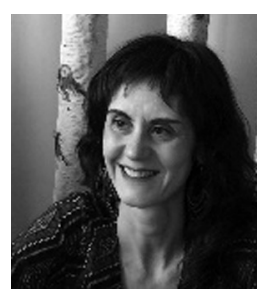

Laura Oso is a full professor at the Department of Sociology and Communication Sciences at the University of A Coruña (Spain). She is the coordinator of ESOMI. PhD in sociology from the Université de Paris I-Panthéon Sorbonne, her research has been oriented towards the study of gender and migration, transnational families, and social mobility. She equally works on the gender, migration, and development nexus. https://orcid.org/0000-0003-1532-6196

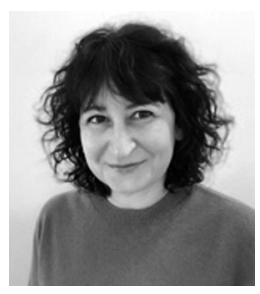

Raquel Martínez-Buján is a senior lecturer at the Department of Sociology and Communication Sciences at the University of A Coruña (Spain). Her research has been oriented towards the study of international migration, sociology of care, sociology of the family, and social policies. Nowadays, her work has focused on the social organization of care, the analysis of the community sphere, and the interpersonal networks of care providers. https://orcid.org/0000-0003-0260-0651 